\title{
THE REFUGEE REGIME AND ITS WEAKNESSES. PROSPECTS FOR HUMAN RIGHTS AND KANT'S ETHIC
}

\author{
JOSEF KOUDELKA
}

\begin{abstract}
When governments create refugee policies they consider several factors (security, economics, ethics, etc.). There are reasons why admitting refugees could have negative consequences (for example, security risks). On the other hand, if the recipient societies have ideals that stress the importance of helping other people, they should act according to their values. The aim of this article is to examine the concept of human dignity and show that European states should admit and help refugees because it is in accordance with their ethical values and the international agreements they have signed. This is important because when European countries hesitate to help refugees, they act not only contrary to their humane tradition, but they can harm them. The western concept of human dignity is one of the main values that stresses that each person is important - that they are equal and free.
\end{abstract}

Key words: refugees; European Union; human dignity; liberalism; Kant; human rights.

\section{Introduction}

Ethnic conflicts, wars, ecological disasters, financial deprivation and political persecution are some of the reasons refugees are forced to try to find new homes. The history of mankind provides many examples of when sometimes even large groups of people have had to flee. One of them is the end of the Cold War when political and ethnic conflicts were felt throughout the world (Barnett, 2002, p. 249) and many people had to leave their homelands. Currently an increasing number of people are having to leave to leave their home countries. According to a report by the Office of the United Nations High Commissioner for Refugees, by the end of 2012, 45.2 million people were considered to have been forcibly displaced (Global Trends 2012). Some of them attempted to reach Europe but as some authors emphasize the EU external border is the deadliest border on earth.

In somewhat less than ten years, since the opening of the internal borders in the EU in 1993, it is estimated that at least 20,000 people have died. And this figure only counts the deaths that were actually found. The Mediterranean Sea and the Atlantic Ocean have become a grave for probably many more bodies (Ferrer-Gallardo \& van Houtum, 2014, p. 297).

The Universal Declaration of Human Rights is an international agreement, guaranteeing a person's right to emigrate from a country. However, many countries have restrictive 
immigration policies and make it difficult for non-citizens to settle. Thus when a person decides to leave his or her country he or she cannot migrate freely. However, the international community has put in place arrangements for countries to help those unable to live in their own countries because of the threat of death, etc. Thus according to the Universal Declaration of Human Rights (article 13) everyone has the right to seek and to be given asylum from persecution in other countries. Equally, the Convention Relating to the Status of Refugees $(1951)^{1}$ and the Protocol Relating to the Status of Refugees $(1967)^{2}$ stress that people are guaranteed asylum if they have a well-founded fear of being persecuted.

Western countries may have good reason to admit refugees not only arising out of their international agreements but because they have an intellectual tradition of helping foreigners. But there are governments who use various ways to reduce the number of refugees seeking entry into their country. Those who are not legally entitled to ask for asylum are regarded as illegal immigrants. They must leave the host country immediately even if they face danger in their homeland. This attitude is problematic and may call into question our conception of human dignity since it implies we do not respect all people, only our fellow citizens. Therefore, if our actions harm refugees (for example, because they are not in accordance with our conception of human dignity), we should consider compensating refugees or letting them in. I believe that we should examine whether our refugee policy is in accordance with human rights and Immanuel Kant's ethic.

The aim of the article is to show that the intellectual tradition of the West and its conceptions of human dignity are an appropriate normative basis for providing greater or real help to refugees and therefore Western states have (or should have) sufficient motivation to help displaced people. Immanuel Kant's emphasis on the importance of each person should be a good basis for our considerations. It reminds us that we should not emphasize unimportant differences (nationality, race, etc.) when creating and implementing immigration policies. I will deal with the moral and political arguments. First, I will show that the current practice of countries is in conflict with their international agreements and provide several examples illustrating how developed countries search for ways to avoid fulfilling international treaties, even once signed. Then I briefly turn to the history of the concept of human dignity and point out that helping foreigners has always been important for our civilization. The next part deals with current liberal theories and their emphasis on human dignity and notes that these theories do not distinguish between different groups of people (on the basis of categories such as nationality). I conclude that the liberal tradition of human dignity (embedded in liberal political theory) could be an appropriate normative basis for admitting refugees. If countries do not act in accordance with their liberal values, they should compensate for the harm done to the refugees.

\section{Erecting barriers against helping refugees}

There are numerous reasons why people cannot remain where they live. People generally become refugees as a result of ethnic, communal and religious conflict, deep socio-economic

\footnotetext{
${ }^{1}$ See http://www.unhcr.org.

${ }^{2}$ See http://www.unhcr.org.
} 
divisions and human rights abuses (Loescher, 1994, pp. 363-364). Recent technological changes (inexpensive air travel, the spread of international communication, etc.) have enabled refugees to claim entry to distant places (Gibney, 1999, p. 169) and therefore the number of asylum seekers travelling to Europe has greatly increased since the early 1980s (Loescher \& Milner, 2003, p. 596). However, since the late 1970s, European unemployment has risen and refugees have come to be perceived as the undeserving beneficiaries of social assistance, putting extra strain on the welfare system (Bade, 2004, p. 343). Despite the real persecution of some refugees, the people of the Global North believe that "the majority of asylum seekers are bogus, that they are actually economic migrants" (Crépeau, Nakache, \& Atak, 2007, p. 331). Indeed, a large majority of economic immigrants present as asylum seekers because European countries have restricted immigration (Pécoud \& Guchteneire, 2006, p. 72). So it is not easy to differentiate between migrants and refugees. ${ }^{3}$

European countries facing an inflow of asylum seekers have started to place restrictions on refugee policies (Bade, 2004, p. 346). It results in asylum seekers and refugees being denied access to international protection or being returned directly or indirectly to frontiers of territories where their life or freedom would be threatened (Crépeau, Nakache, \& Atak, 2007 , p. 312). Countries use various ways to water down their commitments to help refugees (or foreigners in general) because they are perceived to be the cause of problems such as higher criminality, higher social expenditure, an increase in unemployment, etc. (Laqueur, 2006; Sartori, 2005; Weiner, 1992; Huntington, 2001).

One way of reducing the number of refugees is to select an idiosyncratic definition of what a refugee is. There are many definitions of the concept. Each state implements the Geneva Convention through its own internal legislation, "which means that it has to adopt the definition, sometimes in modified form, and then interpret and apply it through its own legal procedures. Some states adopt a much broader interpretation than others" (Carens, 2006, p. 103). The resulting definition can affect the level of assistance provided to refugees. Moreover, neither the Convention Relating to the Status of Refugees nor the Protocol Relating to the Status of Refugees is unproblematic. The Convention and the Protocol do not include some basic needs and the focus is on persecution. According to the Convention, a refugee is a person who

owing to well-founded fear of being persecuted for reasons of race, religion, nationality, membership of a particular social group or political opinion, is outside the country of his nationality and is unable or, owing to such fear, is unwilling to avail himself of the protection of that country; or who, not having a nationality and being outside the country of his former habitual residence as a result of such events, is unable or, owing to such fear, is unwilling to return to it. (Convention relating to the Status of Refugees ${ }^{4}$ ).

But some victimized persons are not granted protection (for instance, persecution because of homosexuality; Wellman, 2010; Shacknove, 1985).

\footnotetext{
${ }^{3}$ Gil Loescher and James Milner point out that persecution and violent conflicts often overlap with economic marginalization, population pressure, environmental degradation or poor governance (Loescher \& Milner, 2003, p. 598).

${ }^{4}$ See http://www.unhcr.org.
} 
Governments also find special ways of reducing the number of asylum seekers. One such way is the concept of a safe country. It means that if a person is a citizen of a country (a safe country of origin) that is democratic, a signatory to the refugee Convention and has a good human rights record, then it is unlikely that he or she is a genuine refugee. If the claimant is not a citizen of this country but has arrived from a "safe country" (a safe third country), then the claimant can be returned to that (third) country where the authorities have to consider the claim. "Therefore, refugee applicants who are citizen of 'safe' countries or who arrive via 'safe' countries are deemed ineligible to make a refugee claim and are treated as illegal entrants" (Bissett, 2002, p. 37).

Even if we assume that the rationale behind the concept is appropriate and safe countries are assigned properly, this system could harm some refugees. The European system of first host country has been criticized because it transfers responsibility for asylum claims to another EU state which analyzes the asylum requests according to its own laws. But it can be a big problem if this country transfers asylum seekers to the country of persecution ${ }^{5}$ (Abell, 1997, p. 572). Another issue is that some Schengen countries are located in areas where there are more asylum seekers (such as Italy or Greece). If these countries have to process large numbers of applications, it may affect the asylum procedure and some persecuted people may be returned. To prevent this situation, other EU countries should try to find ways of helping them. According to some critics, the safe third country concept is also unconstitutional because it deprives asylum seekers of the right to a full hearing in a particular country. "It is also argued that there are no guarantees that a designated safe third country would readmit asylum seekers, which could lead to refugees 'in orbit,' who could end up in their country of origin, given that an agreement with the prescribed country is not a requirement for the return of an asylum seeker" (Abell, 1997, p. 578).

In order to restrict entry to refugees, governments also sanction airline and ferry companies that transport undocumented immigrants into their territories. If an airline or ferry company brings undocumented aliens into the European Union, they must be transferred back. "While applicants for refugee status are exempt, given that the definition of a refugee is not simple, it leaves the staff of the airline or ferry company in the country of departure having to make decisions that potentially leave individuals open to gross human rights violations" (Gilbert, 2004, p. 971). Since airline and ferry companies do not want to be sanctioned, they do not bring in refugees without valid entry documentation (i.e. a visa) into the EU. Sanctions and restrictive visa regimes prevent refugees from benefitting from non-refoulement ${ }^{6}$

\footnotetext{
${ }^{5}$ Abell gives the example of refugees from Iran and Afghanistan travelling through Turkey and Pakistan (so-called countries of first asylum) before reaching Greece, the first EU state. "From Greece they travel to other European countries which, in turn, return them to Greece because, according to the Dublin and Schengen Conventions, it is the country responsible for the asylum claim. According to Greek law, asylum seekers arriving via third countries are to be returned to those countries, in this example Turkey or Pakistan" (Abell, 1997, p. 572).

${ }^{6}$ This principle of international law should protect refugees from being returned to problematic states. "No Contracting State shall expel or return ("refouler") a refugee in any manner whatsoever to the frontiers of territories where his life or freedom would be threatened on account of his race, religion, nationality, membership of a particular social group or political opinion" (Convention and Convention Relating to the Status of Refugees, Article 33).
} 
(Gilbert, 2004, pp. 971-972). The United States and some European countries have also introduced other non-arrival or non-entry tools to create barriers against a new influx of asylum seekers. For example, isolating applicants and processing asylum applications at military bases abroad (the United States processes Haitians at the Guantanamo base in Cuba) and safety zones within the home country where individuals receive international assistance and protection (Kurdish refugees in Iraq and Bosnian refugees in Bosnia-Herzegovina). Some of these policies developed at the national level have been implemented into EU law (Kjaerum, 2002, pp. 515-516).

As shown by these examples, some countries try to minimize their commitments to admitting displaced people. ${ }^{7}$ There are many reasons why countries do not want to admit refugees or any immigrants. They are often perceived to be a problem and burden to society. Critics of more open immigration policies stress that foreigners are a threat to national security and the welfare state and increase unemployment, etc. (Weiner, 1992; Sartori, 2005; Huntington, 2001, etc.). Immigrants raise crime levels because they "face acculturation problems that natives do not, and immigrants tend to settle in disorganized neighbourhoods characterized by deleterious structural conditions such as poverty, ethnic heterogeneity, a preponderance of young males, and possibly more criminal opportunities in the form of gangs" (Martinez, Jr. \& Lee, 2000, p. 514). Critics emphasize that countries do not adequately solve the problems caused by immigrants because policemen of European states do not question these criminal cases and courts do not punish them, and if they arrest immigrants EU institutions and activist groups accuse them of doing it illegally (Laqueur, 2006, pp. 82-83). The validity of these arguments is outside the scope of the paper. However, there are also very different arguments which emphasize that immigration does not increase unemployment or that it is not a threat to the welfare state (Caplan, 2012; Wellman, 2010; Drbohlav, 2011), that foreigners are not a threat to national security (Kukathas, 2005), that immigrants do not increase crime levels (Stowell \& Martinez, 2007; Bianchi, Buonanno, \& Pinotti, 2010; Koudelka, 2014), etc.

Therefore, if people do not see immigrants as enriching their societies, helping refugees would mean that they have to make a sacrifice, simply because they do not feel any obligation to share their wealth with refugees and help them. According to these critics, solidarity is generally possible in a political community. People are only willing to help other members of their nation. "Nations are communities of obligation, in the sense that their members recognize duties to meet the basic needs and protect the basic interests of other members" (Miller, 1995, p. 83). Not all members of the political community need know one another

\footnotetext{
${ }^{7}$ The trouble is that the refugee conventions are not enforceable. International agreements state that refugees have the right to seek and enjoy asylum, but they do not impose a correlative obligation upon the states. Although the office of the United Nations High Commissioner can offer assistance and protection, "decisions to grant asylum after a person has entered a host country remain the prerogative of individual states" (O'Neill \& Spohn, 1998, p. 86). There is no effective enforcement which could guarantee protection. As Myron Weiner writes, the refugee conventions (and hundreds of treaties adopted by UN organizations) were drawn up with little attention to enforcement. UN organs have increased efforts to induce states to carry out their legal obligations. There are, however, only a few such procedures like reporting, monitoring, the threat of expulsion from international organization and trade and investment sanctions (Weiner, 1998).
} 
personally. "A shared identity carries with it a shared loyalty, and this increases confidence that others will reciprocate one's own co-operative behaviour" (Miller, 1995, p. 83). Mutual trust is important because without it, people will not subscribe to social justice, especially schemes involving redistribution to the poor (Miller, 1995, pp. 83-93). On the other hand, a less restrictive policy could be conceptualized, one that does not coerce people and stop them from moving, renting from willing landlords and applying for jobs offered by willing employers. That means it would not impose any cost on citizens.

\section{Human dignity and its importance in Europe}

However, there are some reasons why helping refugees is as important as helping fellow citizens. One of them is the principle of human dignity, which has long history in Europe. In constitutional law and political life in liberal democracies, it cannot be simply brushed aside. Human dignity has at least three elements. Every person possesses (1) an intrinsic worth, merely by being human; and this intrinsic worth (2) should be recognized and respected by others, and some kinds of treatment by others are inconsistent with respect for this worth. And this intrinsic worth requires that (3) the state should exist for the sake of individuals (McCrudden, 2008, p. 679). This concept is not ordinarily used to justify the need to help refugees. Usually theorists think about the pros and cons of immigrations, about freedom of movement, the obligations of Western countries to help poor countries, etc. But they do not often emphasize that all people have one dignity and therefore we should help all people, not only fellow citizens.

This concept is fundamental to Western thought. One of the first philosophical traditions to employ this concept was stoicism. However, Christianity (and Judaism) was more important, laying down the foundations of our attitudes towards human beings. Christianity dominated for many centuries and its influence was extensive (on culture, education, ethics, philosophy, etc.). Christianity integrated medieval states and created a single civilization (Dorotíková, 2009, pp. 57-60; Woods, 2012, pp. 1-7). According to the Holy Bible "God created man in his own image, in the image of God he created him, male and female he created them" (Genesis 1.26). So all people share a common origin and there were no differences among them when they were created. Although people differ in various ways, "their place in this world may be different, but their nature is one" (Aquinas, 1842, Chapter 8). Each person has his/her dignity because God gives him/her a rational nature, as Aquinas puts it (Sousedlík, 2011, p. 12).

Moreover, Christianity emphasizes a strong obligation to help displaced people because no one is in a position to know if the foreigner they meet is not Jesus himself.

The possibility that Jesus might come in the guise of a stranger powerfully broadens and intensifies concerns about care and respect for those likely to be overlooked. This passage, more than any other, has undergirded the Christian hospitality tradition, and continues to shape the response of practitioners to this day (Pohl, 2006, pp. 90-91).

As Petr Štica argues, Christians perceived themselves to be strangers because Earth belongs to God. They thought that their earthly life was transitory and heaven would be the place they lived in forever. However, this alienation does not mean withdrawal from 
society. Paradoxically, at the beginning of Christianity Christians were open to converts, with the exception of Jews. They were also hospitable to strangers (Štica, 2010, pp. 76-78). The roots of this Christian openness can be traced back to the Old Testament where the instruction to love the sojourner was conveyed in the requirement to provide protection and minimal provisions. The expectation that Israel would understand and respond to the plight of sojourners was based on its own experience of its people being mistreated aliens in Egypt (Pohl, 2006, p. 87).

In modern Catholic social teaching, countries are said to be morally bound not only to respect and promote the basic rights of their citizens, but also to pay attention to those individuals whose rights are most imperilled. People are entitled to be treated in accordance with their equal dignity. "The duties of states to aid and protect migrants and refugees presume the antecedent duty of preserving an international social order (the global common good) in which the basic rights of most vulnerable are protected" (O'Neill \& Spohn, 1998, p. 101). Roman Catholicism stresses that states should assist those who are persecuted.

The Christian version of human dignity has affected the European attitude to individuals. "It seems clear that the combination of the Enlightenment, republican, socialist/social democratic, and Catholic uses of dignity together contributed significantly to these developments, with each being more or less influential in different countries" (McCrudden, 2008 , p. 664). The principle of equal dignity is now accepted as a minimum standard throughout mainstream Western culture. Any political theory abandoning equal dignity will not be found plausible today (Gosepath, 2007, section 2.3). European history exhibits a trend of gradually awarding dignity to various groups of citizens (not only in theory but also in practice). For example, after the French Revolution dignity was extended to every citizen by the Declaration of the Rights of Man and of the Citizen. "The subsequent development of dignity drew substantially on the importance of Man as having the capacity of reason, whilst dropping the religious elements of humanist writings" (McCrudden, 2008, p. 659). According to the democratic and liberal conceptions, human dignity belongs to all individuals (Taylor, 2001, p. 43).

The use of the concept in legal documents can be traced back to the first three decades of the 20th century when several countries in Europe and the Americas incorporated the concept of dignity into their constitutions. ${ }^{8}$ The concept of dignity also appears in the Universal Declaration of Human Rights, where it is mentioned several times. It states all human beings are born free and equal in dignity and rights (Article $1^{9}$ ). Generally speaking,

\footnotetext{
${ }^{8}$ The concept of human dignity has become more important since the end of the World War II and it has been used to justify human rights in international and national laws. This is the result of several factors, and the historical conditions that have made us attentive to mass crimes and the process of globalization are the most important ones. The international community has sought to limit violence and construct a just global world and to help more people live more dignified lives. "With the images from the Nazi death camps, Hiroshima, Cambodia, Rwanda and other atrocities showing how people were tortured and killed and with the growing realization of the consequences of various types of discriminatory systems which used the institutional language of disrespect (sexism, apartheid, discrimination of minorities), people increasingly recognized the importance of human rights for international justice" (Misztal, 2013, p. 110)

${ }^{9}$ See http://www.un.org/en/universal-declaration-human-rights/index.html
} 
human dignity is a widely accepted fundamental value in liberal democratic countries, and it has been underlined by its preeminent place in modern constitutional systems (Rao, 2011, p. 270). Some theorists also consider human dignity to be an important source of justification for human rights. For example, Jiří Baroš emphasizes that the German and Czech constitutional courts founded their judiciaries on the concept of human dignity, which then becomes the deepest, paramount value of the constitutional order (Baroš, 2013; Baroš, 2012, pp. 55-70). However, the principle of human dignity is fundamental to other European constitutions (see, e.g., Klokočka \& Wagnerová, 1997) and therefore constitutional courts have to reflect it. "Human dignity has also been incorporated judicially as a general principle of European Community law, deriving from the constitutional traditions common to Member States" (McCrudden, 2008, p. 683).

\section{Kant's fundament of liberal conception of human dignity}

The emphasis on dignity is more important for liberalism and its conception of human beings. The liberal state is obliged to affirm the dignity of all individuals because it fundamentally values liberty, personal autonomy and equality (Preece, 1998, p. 151). Liberalism emphasizes the importance of all individuals and proclaims that the human dignity of each should be respected. David Boaz believes that this liberal attitude towards individuals is expressed well in Immanuel Kant's ethics. He believed people should treat humanity never merely as a means to an end, but always at the same time as an end (Boaz, 2002, p. 98). Kant was the first major Western philosopher who emphasized that each person should be respected and that individuals were ends in themselves with absolute dignity. This has become a core ideal of modern humanism and political liberalism (Dillon, 2014).

He emphasized that all people are free and equal; they can create moral laws for themselves and motivate themselves to follow these rules. In order to do that, they need to test whether they "act only in accordance with that maxim through which you can at the same time will that it become a universal law" (Kant, 2002, p. 37). When they do it individually they should not favour their personal inclinations but their rational will. To be able to determine himself/herself, each person needs freedom (Kant, 1996, pp. 226-229). Individuals are constrained by themselves to consider the point of view of other people, not only the people one loves but all individuals. "Act so that you use humanity, as much in your own person as in the person of every other, always at the same time as end and never merely as means" (Kant, 2002, pp. 46-47). This means that Kant posits the human being as the ultimate end (Sousedlík, 2011, pp. 15-16).

Kant's ethic is not limited to the members of one country or society.

The growing prevalence of a (narrower or wider) community among the peoples of the earth has now reached a point at which the violation of right at any one place on the earth is felt in all places. For this reason the idea of cosmopolitan right is no fantastic or exaggerated conception of right (Kant, 2006, p. 84).

However, although Kant has widely influenced cosmopolitan thinking, not least on global justice, his version of international justice represented an attempt to reconcile strong moral cosmopolitanism with a rejection of a "world-state" because in his view there was a danger 
of global despotism and paternalism. For this reason, Kant proposed the general principles of an international law to set up a federation of sovereign states, coupled with the cosmopolitan right of hospitality (Dufek, 2013, p. 183). Hospitality is the right of a stranger not to be treated in a hostile manner by citizens upon his arrival on the other's territory. The host does not have the right to refuse anyone. "If it can be done without causing his death, the stranger can be turned away, yet as long as the stranger behaves peacefully where he happens to be, his host may not treat him with hostility" (Kant, 2006, p. 82). So although Kant emphasized that all people had the right to travel freely around the globe, he did not think they had the right to live anywhere they wanted. Only if somebody is in danger and might die, should the host (state) help. Therefore if we do not help refugees, we violate the rights of other people, no matter where on planet Earth they live.

\section{Liberalism, human dignity and refugees}

Many liberal philosophers follow Kant in emphasizing the importance of each person. $\mathrm{He}$ thought that individuals should not merely be treated as means and that they should not be sacrificed or used to achieve other ends without their consent. For liberals people are primarily ends as Robert Nozick emphasizes (Nozick, 1999, p. 31). No human life should be wasted because there is "no ground for distinctions of degree any more than for flat exclusions" (Dworkin, 2006, p. 16). Although John Rawls thinks that immigration should be restricted (Rawls, 1999, p. 8), he emphasizes that the rights of each individual should not be neglected.

Each person possesses an inviolability founded on justice that even the welfare of society as a whole cannot override. For this reason justice denies that the loss of freedom for some is made right by a greater good shared by others. It does not allow that the sacrifices imposed on a few are outweighed by the larger sum of advantages enjoyed by many (Rawls, 2005, pp. 3-4).

Although he did not create A Theory of Justice to solve the question of immigration, we can presume that because the individuals in the original position are members of the same nation-state people favour free movement. For example, Cécile Fabre emphasizes that those in the original position should not know where they live

As they are risk-averse and do not know anything about their personal circumstances, it seems that they would opt for a policy of relatively open borders. If one does not know which country one resides in, one does not know whether one will need to settle in another country for economic or political reason (Fabre, 2007, p. 18).

Michael Pakaluk thinks that the concept of human dignity could be important for Theory of Justice because when Rawls writes the book he comes very close to offering an account of human dignity (Pakaluk, 2007, p. 21). ${ }^{10}$ Liberal societies should test whether human dignity is not simply an ideal and whether non-citizens are treated in accordance with their dignity.

\footnotetext{
${ }^{10}$ However, in Political Liberalism Rawls "insists that political philosophy should apply the Principle of Toleration to itself, and thus it should not rely on philosophical or metaphysical notions" (Pakaluk, 2007, p. 21).
} 
We can examine the ordeal of young women from immigrant families who have to liberate themselves from the violence of traditional code of honour or the brutal expulsion of illegal immigrants and asylum seekers (Habermas, 2012, p. 467). Moreover, this attitude can help citizens improve their own conceptions of human dignity and human rights.

In the light of such specific challenges, different aspects of the meaning of human dignity emerge from the plethora of experiences of what it means to be humiliated and be deeply hurt. The features of human dignity specified and actualized in this way can then lead both to a more complete exhaustion of existing civil rights and to the discovery and construction of new ones (Habermas, 2012, pp. 467-468).

As we can see above, Western states have gradually awarded human dignity to various groups of people. We can presume that this positive trend will continue until there is no group of people without human dignity. Despite the existence of many international agreements that grant formal rights to refugees, the human dignity of refugees is not sufficiently respected. Perhaps it is time we included them as well.

\section{Human dignity and the harm principle}

A consistent attitude to refugees requires taking them into full consideration because they are human beings and therefore any government should at least create and implement a refugee policy that does not unnecessarily harm human beings, in this case refugees. Trying to save the lives of refugees is in accordance with the liberal democratic tradition and its values. Since a lot of Western countries have restrictive refugee policies, governments cannot believe that if they do not admit refugees they will be able to find another country that will willingly help them. So if we do not allow entry to refugees who do not have enough alternatives to find a place where they can settle or enter, we may cause harm to them. If we refuse to admit refugees, we should provide a justified reason why we could not help them and we should check whether there is real possibility that the refugees could be admitted elsewhere. As Shelley Wilcox emphasizes, no agent should harm other agents. If harm has already been caused, the victims must be compensated. "[S]ince all persons deserve equal moral respect, there are no legitimate grounds for claiming that harm to non-citizens is any less morally problematic than harm to citizens" (Wilcox, 2007, pp. 277-278).

This version of the principle is not only about John Stuart Mill's limits on a person's freedom to prevent harm to other individuals. The "Harm Principle" stresses that to impose harm upon someone is to treat him or her without moral respect or exclude them from the realm of obligation. This concept provides "a means for balancing competing claims to human loyalties. Such a principle refers to the minimal duties that communities and their citizens ought to owe each other and outsiders" (Shapcott, 2008, p. 204). Richard Shapcott thinks that the principle can be interpreted as a principle of universal equality, such as Kant's categorical imperative. Differences of nationality and race should not count as reasons to restrict, exclude, or deny a person's obligations to treat others as moral equals. This liberal/ cosmopolitan version of the Harm Principle does not require a radical change of the world order. Even in a non-cosmopolitan world where a lot of people give priority to their local community we can try to treat others as ends in themselves, which implies that we should not 
harm them and make them suffer. "At its simplest it means that 'our' economic well-being cannot come at the expense of the survival or suffering outsiders" (Shapcott, 2008, p. 203). Kant's emphasis on acting to use humanity as an end and never merely as a means became an important principle and human dignity which is embodied in democratic constitutions (Beitz, 2013, p. 270).

We should not do what is bad for other people and if possible we should find solutions which are better for them. "There is a duty to cease harming, which involves a duty to prevent further harm from the imposition of an equally bad alternative world order; thus we should stop harming and make sure we do not harm again" (Shapcott, 2008, p. 202). But it is not only the world order that impacts on non-citizens. Bad refugee policies can seriously harm people and their dignity.

\section{Conclusion}

The European conception of human dignity and its long tradition (in stoicism, Christianity, etc.) stresses that we should have the motivation to help those unknown to us. Europe has also been strongly influenced by Kant's version of human dignity in which dignity belongs to everyone simply because people are rational beings. Agents should consider the point of view of other persons, not only those whom we love but all individuals. We should always use the humanity in each person at the same time as an end and never merely as a means. Kant's conception of human dignity has influenced the development of philosophy, especially liberalism and cosmopolitism. Human dignity not only became the dominant value in current moral and political philosophy, but the concept is also the foundation of many liberal constitutions. Despite us not always being sure about the meaning of Kant's work, he was clear on the fact that we should not refuse to help refugees when we may cause their death. If we do refuse, we violate the rights of other people, no matter where they live.

Although the Western concept of human dignity stresses that there are no differences among people, we can see that European countries have marginalized the problems of refugees and tried to find ways to reduce the amount of displaced persons whom they are willing to admit. There is a large gap between formal international agreements and actual policy. As Julian Burnside says, the refugee problem involves a choice between minor selfsacrifice and major betrayal of humanitarian standards (Burnside, 2002, p. 18). However, Western tradition stresses that there is the only one conception of human dignity - that all people are equal. Therefore, even if we prefer to help our fellow citizens, in some cases we should not hesitate to find ways to save the human lives of refugees or help people who are unjustly persecuted. Refugees need at least temporary protection until they are able to return to their home countries.

Some refugees have to leave their homelands and are then not able to find new homes, and some of them are even imprisoned. If we do not admit refugees or help them, some may suffer physical and psychological harm not only because they do not live safely in their own countries but also because we have added to their problems. Our reasons may vary but as Kant emphasized we should use humanity as an end and never merely as a means. Above all we should see that these refugees are human beings, not that they might potentially influence our overall crime rate, unemployment, etc. We cannot be certain that their presence will 
have negative effects on our societies. Moreover, what is now considered to be a serious reason for restricting them may later not be regarded as sufficient reason to exclude them. Therefore, we should help them (or at least we should not prevent them from helping themselves or seeking help from others) because of the concept of human dignity itself. If we relativize their problems, we question the general validity of this concept. So "we must treat them decently: for the sake of their humanity, and for the sake of our own humanity. The way we are treating them diminishes us" (Burnside, 2002, p. 27). When we are not able to admit refugees, we need to find ways of providing relief to them in their difficult situation. Our refugee policies and practices should be consistent with our ideals and the liberal conception of human dignity. It also means that liberal politicians should not encourage the rise of anti-immigrant or even anti-democratic sentiment in societies because it may be a threat to the future of the liberal state. They should not use this issue to gain votes in elections. On the contrary, they could state why refugees should be admitted instead of only emphasizing potential threats. ${ }^{11}$

\section{References}

Abell, N. A. (1997). Safe country provisions in Canada and in the European Union: A Critical assessment. International Migration Review, 31(3), 569-590.

Aquinas, T. (1842). Catena Aurea: Gospel of Matthew. London: JGF and J. Rivington.

Bade, K. J. (2004). Evropa v pohybu. Evropská migrace dvou staletí. [Europe on the move. Two centuries of European migration]. Praha: Lidové noviny.

Barnett, L. (2002). Global governance and the evolution of the international refugee regime. International Journal of Refugee Law, 14(2/3), 238-262.

Baroš, J. (2012). Svoboda a rovnost v důstojnosti a právech. Základní práva a svobody obecně [Freedom and liberty in dignity and rights. Basic rights and liberties: In general]. In E. Wagnerová, V. Šimíček, \& T. Langášek (Eds.), Listina základních práv a svobod: komentář. [Charter of basic rights and freedoms: Commentary], (pp. 55-70). Praha: Wolters Kluwer.

Baroš, J. (2013). Mezi lidskými právy a suverenitou - koncepty politické filosofie a jejich aplikace v realitě České republiky. [Between human rights and sovereignty - concepts of political philosophy and their application in the reality of the Czech Republic]. Brno: Thesis.

Beitz, C. R. (2013). Human dignity in the theory of human rights: Nothing but a phrase? Philosophy \& Public Affairs, 41(3), 259-290.

Bianchi, M., Buonanno, P., \& Pinotti, P. (2010). Do immigrants cause crime? (http://www.cepremap. ens.fr/depot/docweb/docweb1023.pdf)

Bissett, J. (2002). A defence of the safe country concept. Policy Options, (6), 36-38.

Boaz, D. (2002). Liberalismus v teorii a praxi. [Libertarianism: A primer]. Praha: Liberální institut.

Burnside, J. (2002). Refugees: the Tampa case. Postcolonial Studies, 5(1), 17-28.

Caplan, B. (2012). Why should we restrict immigration? Cato Journal, 32(1), 5-24.

Carens, J. H. (2006). Who should get in? The ethics of immigration admissions. Ethics \& International Affairs, 17(1), 95-110.

Crépeau, F., Nakache, D., \& Atak, I. (2007). International migration: Security concerns and human rights standards. Transcultural Psychiatry, 44(3), 311-337.

Dillon, R. S. (2014). Respect. Stanford encyclopedia of philosophy (http://plato.stanford.edu/entries/ respect/)

\footnotetext{
${ }^{11}$ The author would like to thank Pavel Dufek for his guidance and critical feedback.
} 
Dorotíková, S. (2009). Filozofické kořeny právního myšlení. [Philosophical roots of legal thinking]. Plzeň: Vydavatelství a nakladatelství Aleš Čeněk.

Drbohlav, D. (2011). Imigrace a integrace cizinců v Česku: Několik zastavení na cestě země v její migrační proměnně z Davida na téměř Goliáše. [Immigration and integration of foreigners in the Czech Republic: Several stops along the way of the Country in its migration transformation from David to almost Goliath]. Geografie, 116(4), 401-421.

Dufek, P. (2013). Why strong moral cosmopolitanism requires a world-state. International Theory, 5(2), 177-212.

Dworkin, R. (2006). Is democracy possible here? Principles for a new political debate. Princeton: Princeton University Press.

Fabre, C. (2007). Justice in a changing world. Malden, Cambridge: Polity Press.

Ferrer-Gallardo, X., \& van Houtum, H. (2014). The deadly EU border control. ACME: An International E-Journal for Critical Geographies, 13(2), 295-304.

Gilbert, G. (2004). Is Europe living up to its obligations to refugees? The European Journal of International Law, 15(5), 943-987.

Gosepath, S. (2007). Equality. Stanford encyclopedia of philosophy. (http://plato.stanford.edu/entries/ equality/)

Habermas, J. (2012). The concept of human dignity and the realistic utopia of human rights. In C. Corradetti (Ed.), Philosophical dimensions of human rights: Some contemporary views (pp. 63-79). Dordrecht: Springer.

Holy Bible: English standard version: Containing the Old and New Testaments. (2001). Wheaton: Crossway.

Huntington, S. P. (2001). Střet civilizací. Boj kultur a proměna světového řádu. [The clash of civilizations and the remaking of world order]. Praha: Rybka Publishers.

Kant, I. (1996). Kritika praktického rozumu. [The critique of practical reason.] Praha: Nakladatelství Svoboda.

Kant, I. (2002). Groundwork of the metaphysics of morals. New Haven, London: Yale University Press.

Kant, I. (2006). Toward perpetual peace: A philosophical sketch. In I. Kant, Toward perpetual peace and other writings on politics, peace, and history (pp. 67-110). New Haven and London: Yale University Press.

Klokočka, V., \& Wagnerová, E. (1997). Ústavy států Evropské unie. [Constitutions of the countries of the European Union]. Praha: Linde.

Kjaerum, M. (2002). Refugee protection between state interests and human rights: Where is Europe heading? Human Rights Quarterly, 24(2), 513-536.

Koudelka, J. (2014). Kriminalita cizinců a imigrační politika. [Crime rate of foreign nationals and immigration policy]. Bezpečnostní teorie a praxe, (1), 103-117.

Kukathas, C. (2005). The case for open immigration. In A. Cohen \& C. Heath Wellman (Eds.), Contemporary debates in applied ethics (pp. 207-220). Malden, MA: Blackwell Publishing.

Laqueur, W. (2006). Poslední dny Evropy: humanistická Evropa nebo islamistická Eurábie?: analýza, perspektiva, prognóza, ř ̌̌ení. [The last days of Europe: The changing face of a continent.] Praha: Nakladatelství Lidové noviny.

Loescher, G. (1994). The international refugee regime: Stretched to the limit? Journal of International Affairs, 47(2), 351-377.

Loescher, G., \& Milner, J. (2003). The missing link: The need for comprehensive engagement in regions of refugee origin. International Affairs, 79(3), 596-617.

Martinez, R. Jr., \& Lee M. T. (2000). Immigration and crime. In G. LaFree, R. J. Bursik, Jr., J. F. Short, Jr., \& R. B. Taylor. (Eds.), The Nature of Crime: Continuity and change (Vol. 1, pp. 485-524). Washington DC: National Institute of Justice. 
McCrudden, C. (2008). Human dignity and judicial interpretation of human rights. The European Journal of International Law, 19(4), 655-724.

Miller, D. (1995). On nationality. New York: Oxford University Press.

Misztal, B. A. (2013). The idea of dignity: Its modern significance. European Journal of Social Theory, 16(1), 101-121.

Nozick, R. (1999). Anarchy, state, and utopia. Oxford: Blackwell.

O'Neill, W. R., \& Spohn, W. C. (1998). Rights of passage: The ethics of immigration and refugee policy. Theological Studies, 59(1), 84-106.

Pakaluk, M. (2007). The dignity of the human person and the philosophy of John Rawls. Conference on The Philosophical foundations of human dignity. Ralph McInerny Center, Washington, D.C., 3 March 2006.

Pécoud, A., \& de Guchteneire, P. (2006). International migration, border controls and human rights: Assessing the relevance of a right to mobility. Journal of Borderlands Studies, 21(1), 69-86.

Pohl, C. D. (2006). Responding to strangers: Insights from the Christian tradition. Studies in Christian Ethics, 19(1), 81-10.

Preece, J. J. (1998). Multiculturalism, dignity and the liberal state in Canada. Politica, 30(2), 149-166.

Rao, N. (2011). Three concepts of dignity in constitutional law. Notre Dame, 86, 183-234.

Rawls, J. (2005). A theory of justice. Cambridge, MA: Harvard University Press.

Rawls, J. (1999). The law of peoples. Cambridge, MA, London: Harvard University Press.

Sartori, G. (2005). Pluralismus, multikulturalismus a přistěhovalci. Esej o multietnické společnosti. [Pluralism, multiculturalism and foreigners: An Essay on multiethnic society]. Praha: Dokořán.

Shacknove, A. E. (1985). Who is a refugee? Ethics, 95(2), 274-284.

Shapcott, R. (2008). Anti-cosmopolitanism, pluralism and the cosmopolitan harm principle. Review of International Studies, 34, 185-205.

Sousedlík, S. (2011). Důstojnost člověka v pojetí Tomáše Akvinského a Immanuela Kanta [Human dignity in the concept of Thomas Aquinas and Immanuel Kant]. In T. Nejeschleba, V. Němec, \& M. Recinová (Eds.), Pojetí člověka v dějinách a současnosti filozofie [The Concept of man in the history and current philosophy] (pp. 9-18). Brno: CDK.

Stowell, J. I., \& Martinez, R., Jr. (2007). Displaced, dispossessed, or lawless? Examining the link between ethnicity, immigration, and violence. Aggression and Violent Behavior, 12, 564-581.

Štica, P. (2010). Cizinec v tvých branách. Biblické podněty pro etickou reflexi migrace. [Stranger within your gates. Biblical incentives for ethical reflection on migration.] Praha: Nakladatelství Karolinum.

Taylor, C. (2001). Politika uznání. [The politics of recognition.] In A. Gutmannová (Ed.), Multikultularismus. Zkoumání politiky uznání. [Multiculturalism: Examining the politics of recognition] (pp. 41-90). Praha: Filosofia.

United Nations High Commissioner for Refugees (2010). Convention and Protocol relating to the status of refugees. (http://www.unhcr.org/3b66c2aa10.html)

United Nations High Commissioner for Refugees (2013). Global Trends 2012. (http://www.unhcr. org/51bacb0f9.html)

Universal Declaration of Human Rights (http://www.un.org/en/documents/udhr/).

Weiner, M. (1992). Security, stability, and international migration. International Security, 17(3), 91126.

Weiner, M. (1998). The clash of norms: Dilemmas in refugee policies. Journal of Refugee Studies, $11(4), 433-452$.

Wellman, C. H. (2010). Immigration. In Stanford encyclopedia of philosophy, (http://plato.stanford. edu/entries/immigration/).

Wilcox, S. (2007). Immigration admissions and global relations of harm. Journal of Social Philosophy, 38(2), 274-291. 
Woods, T. E. (2012). How the Catholic Church built western civilization. Washington: Regnery Publishing.

Department of Political Science,

Faculty of Social Studies,

Masaryk University,

Joštova 10 ,

60001 Brno,

Czech Republic

E-mail: koudelkapv@seznam.cz 